Poetic Language 



\title{
Poetic Language
}

Theory and Practice from the Renaissance to the Present

\author{
Tom Jones
}

EDINBURGH

University Press 
(C) Tom Jones, 2012

Edinburgh University Press Ltd

22 George Square, Edinburgh EH8 9LF

www.euppublishing.com

Typeset in 10.5/12.5 Adobe Goudy

by Servis Filmsetting Ltd, Stockport, Cheshire, and

printed and bound in Great Britain by

CPI Group (UK) Ltd, Croydon, CR0 4YY

A CIP record for this book is available from the British Library

ISBN 9780748656172 (hardback)

ISBN 9780748656165 (paperback)

ISBN 9780748656189 (webready PDF)

ISBN 9780748656202 (epub)

ISBN 9780748656196 (Amazon ebook)

The right of Tom Jones

to be identified as author of this work

has been asserted in accordance with

the Copyright, Designs and Patents Act 1988. 